\title{
Modeling for transboundary water resources planning and allocation: the case of Southern Africa
}

\author{
D. Juízo ${ }^{1}$ and R. Lidén ${ }^{2}$ \\ ${ }^{1}$ Universidade Eduardo Mondlane, Faculdade de Engenharia, Av. de Moçambique, CP 257, Km 1.5, Maputo, Moçambique \\ ${ }^{2}$ Lund University, Department of Water Resources Engineering, P.O. Box 118, 22100 Lund, Sweden
}

Received: 9 January 2008 - Published in Hydrol. Earth Syst. Sci. Discuss.: 19 February 2008

Revised: 6 October 2010 - Accepted: 15 November 2010 - Published: 26 November 2010

\begin{abstract}
International water resources agreements for transboundary rivers in southern Africa are generally founded in system analysis models for water planning and allocation. The Water Resources Yield Model (WRYM) developed in South Africa has so far been the only model applied in official joint water resources studies aimed to form watersharing agreements. The continuous discussion around the model performance and growing distress over it being South African, where it was originally developed, while South Africa is one of the interested parties in the process, results in an increased controversy over the system analysis results that are often only meant to guide in selecting the options for water resources management in a given set of scenarios. The objective of this study was therefore to assess the model performance of two other models; WAFLEX and WEAP21 in the Umbeluzi River Basin system where the WRYM was previously applied as part of a Joint River Basin Study. A set of basin development scenarios was equally tested in the three models and the results compared. The results show that the three models all are possible tools for system analysis of river basins in southern Africa, although the structure and complexity of the models are different. The obtained level of satisfaction for specific water users could, however, vary depending on which model was used, which causes uncertainties. The reason for the diverse results is the structurally different ways of describing allocation and prioritization of water in the three models. However, the large degrees of freedom in all system models cause even larger uncertainty in the results since the model developer can, intentionally or unintentionally, direct the results to favor certain water user. The conclusion of this study is therefore that the choice of model does not per se affect the decision of best water allocation and infrastructure layout of a shared river basin. The chosen
\end{abstract}

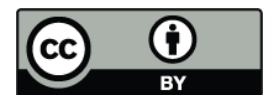

Correspondence to: D. Juízo (juizo@hotmail.com) allocation and prioritization principles for the specific river basin and the model developer's experience and integrity are more important factors to find the optimal and equitable allocation.

\section{Introduction}

Water resources systems are generally complex with both qualitative and quantitative factors governing water resources availability (Raju and Pillai, 1999). In southern Africa the high climatic variability further adds the complexity. Both the large seasonal variations and the interannual variations, with long dry spells, make infrastructural solutions necessary to assure water availability at all times. The role of reservoirs in water resources management in Southern Africa is highlighted by van der Zaag and Bolding (2005).

However, building infrastructures will not on its own ensure water availability and equitable water allocation between countries and users of a particular river basin. The system of natural and regulated water resources should be utilized and managed appropriately for sustainable use of the water resources. In southern Africa, decision on water resources permit allocation between different users and between different riparian countries is therefore commonly based on system analysis tools. System analysis tools are adequate to evaluate and propose the best management strategies towards maximization of benefits for a given number of users under given objective functions in the catchment. As pointed out by Dent (2001) “... a model is a tool to help organize a negotiation or learning process in which its primary function is to provide a framework for thinking by enabling participants to make their implicit assumptions explicit in a systematic manner". Despite being a simplification of a complex water resources system, a system analysis model gives the opportunity for decision makers to know beforehand the consequence of a chosen management option or scenario,

Published by Copernicus Publications on behalf of the European Geosciences Union. 
though, within the limits imposed by the uncertainty in data and gaps in the knowledge of the processes involved in natural systems. These tools are therefore important instruments for authorities and governments to adopt policies for water resources management in both national and transboundary river basins. However, because the stakeholders or countries objectives often are conflicting it is necessary that the model or software used is considered unbiased.

In southern Africa the countries have not yet agreed on the set of decision support tools that should apply in the water allocation process. The experience from the already implemented joint system analysis studies in Umbeluzi and Incomati rivers in southeast Africa (Consultec and BKS Acres, 2000; SWECO and Associates, 2005) has shown preference to the Water Resources Yield Model (WRYM) as the tool adopted for system analysis. The experience from these studies, however, shows that the results obtained from WRYM are not easily understood by the stakeholders, and government representatives of different countries bear some suspicion about the results from the system analysis. The lack of trust in the system analysis tool has prevented a smooth negotiation on transboundary water resources allocation, focusing the discussion on the nature and properties of the tools rather than the strategies that can be applied to improve water resources allocation between countries.

Water resources system analysts are challenged to produce a system analysis model that considers both the legal framework and the true behavior in the system. Stakeholders often share water resources at very local level and rely mostly on customary principles embodied in local level institutions (van der Zaag and Bolding, 2005). Integrating small stakeholders in a large-scale river basin management thus needs harmonization of local and regional interests. In the case a water release in a large basin targets the most downstream user, e.g. environment flow to the estuary, all the local water users along the river must have a corresponding objective not to use this water, otherwise the reserved water will gradually be used by the local users starting with the most upstream community. This situation is even more difficult in transboundary rivers. In such a situation the question is: how complex should a system analysis model be to handle this scale problem but at the same time be sufficiently transparent and uncomplicated to give stakeholders information for setting and accepting allocation criteria?

This study examines the role that decision support tools play in the agreement process by evaluating three different system analysis model packages for water allocation for the same river basin, the Umbeluzi River in Swaziland and Mozambique. The objective is to compare these models in terms of complexity, reliability of results, transparency and to assess whether the model selection may affect the decision of best water allocation and infrastructure layout of a shared river basin.

\section{Material and methods}

Because the WRYM is the preferred model tool for system analysis of international river basins in the SADC region (Carmo Vaz and van der Zaag, 2003; van der Zaag and Carmo Vaz, 2003) a comparative analysis of model performance was conducted through applying two other models in a river basin where the WRYM had been applied. As a case study it was chosen to do the assessment in the Umbeluzi River in which the WRYM has previously been set up as part of the Joint Umbeluzi River Basin Study (JURBS) that aimed to prepare the baseline for a new water resources sharing agreement between Swaziland and Mozambique (SWECO and Associates, 2005). The Umbeluzi River basin was chosen because it is a relatively simple water resources system which is faced with some of the core challenges of transboundary rivers in southern Africa: high climatic variability, scarce water resources, upstream versus downstream users, large-scale versus small-scale users and significant environmental flow requirements. The challenges for water resources management in the Umbeluzi River basin have previously been studied by Juizo et al. (2006).

The basis for the study was that the different models would apply the same inputs and configuration as was used in the study by SWECO and Associates (2005). As a first step the WRYM model runs by SWECO and Associates (2005) were reproduced to simulate a set of different development scenarios for the Umbeluzi River basin. Secondly a spreadsheet based system analysis model, WAFLEX, and a corresponding GIS based software, WEAP21, were set up for the Umbeluzi River and applied for the same development scenarios. The WAFLEX model has been used previously in analyzing other river basins in SADC region, namely the Incomati, Maputo and Save (Nkomo and van der Zaag, 2004; Sengo et al., 2005; de Groot and Oosterwijk, 2006; Symphorian et al., 2003). While the WEAP21 was used in the Olifants river a tributary to Limpopo river (Lévite and Sally, 2002; Le Roy, 2005).

\subsection{The Umbeluzi River basin}

The headwater of the Umbeluzi River is located in Swaziland close to its western border with South Africa (Fig. 1). The river flows in an easterly direction and discharges into the Indian Ocean via the Espirito Santos estuary south of Maputo City in Mozambique. The total catchment area of the Umbeluzi River basin is $5400 \mathrm{~km}^{2}$ (SWECO and Associates, 2005). $40 \%$ of the area is in Mozambique, $58 \%$ in Swaziland and only $2 \%$ in South Africa. Two major tributaries join the main river, the White Umbeluzi in Swaziland and the Movene in Mozambique.

The altitude increases from the sea level to almost $2000 \mathrm{~m}$ a.s.l. in the western part. Rainfall varies from $500 \mathrm{~mm} /$ year in the lower parts to $1500 \mathrm{~mm} /$ year in the mountainous part. The basin experiences two distinct 


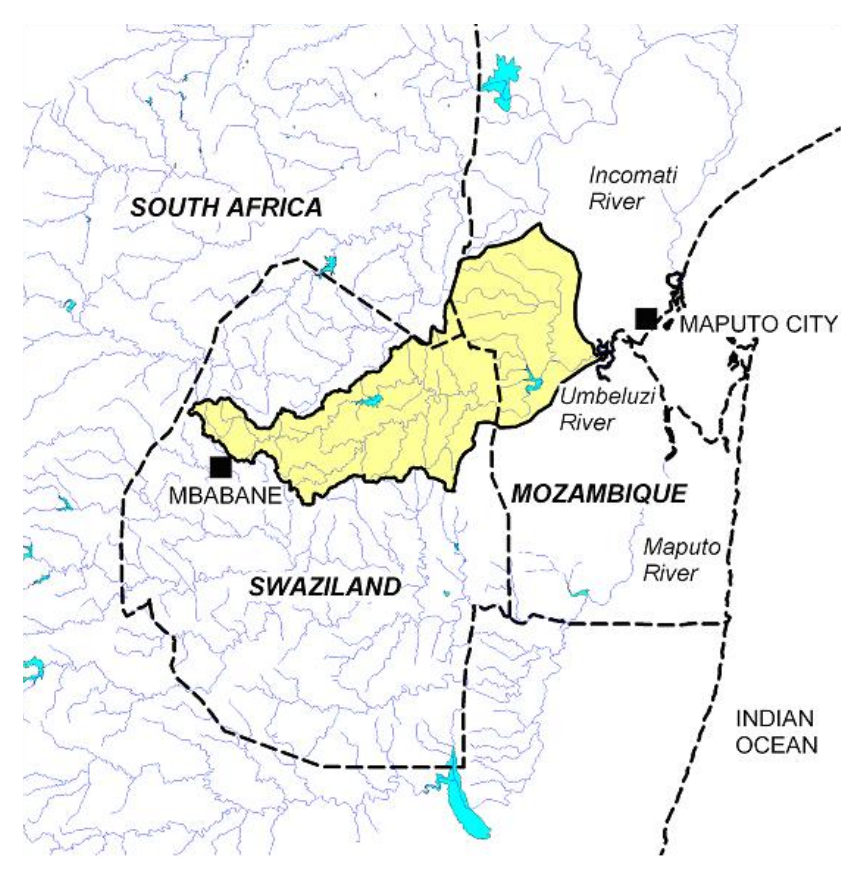

Fig. 1. The Umbeluzi River basin.

seasons; the rainy season from November to April and the dry season between May and October. Two major dams are located in the basin. The Mnjoli Dam, with total capacity of 152 million $\mathrm{m}^{3}$ was built in 1978 with purpose to secure water for the sugar cane estates in eastern Swaziland. The Pequenos Libombos Dam in Mozambique, with total capacity of 385 million $\mathrm{m}^{3}$, was constructed in 1987 mainly to secure the urban water supply for Maputo City. The intake and water treatment plant for Maputo City is located some kilometers downstream of the Pequenos Libombos and the dam is therefore constantly releasing a minimum flow to allow for water supply. In addition, a small dam in the upper basin in Swaziland, the Hawane $\left(2.75\right.$ million $\left.\mathrm{m}^{3}\right)$, supplies the capital Mbabane with fresh water.

The largest water user in the Umbeluzi basin is irrigation as can be deduced from the water demands (Table 1). The sugar cane estates in eastern Swaziland stand for more than $70 \%$ of the present water demand. The total estimated present water demand for surface water is 350 million $\mathrm{m}^{3} / \mathrm{year}$ but is forecasted to increase to 586 million $\mathrm{m}^{3} /$ year by the year 2025 . The available water, under natural conditions, is estimated to be 535 million $\mathrm{m}^{3} /$ year (SWECO and Associates, 2005). The two countries have a number of small-scale users distributed in the catchment and because of the water scarcity many proposals exist to build storage infrastructure.

A simplified schematic of the Umbeluzi water resources system, for the present infrastructure development, is shown in Fig. 2. In the schematic is shown the subbasins generating natural runoff, main water users, channels links, dams and
Table 1. Water demands in Umbeluzi River (MCM/yr). Source: SWECO and Associates (2005).

\begin{tabular}{lrrrrrr}
\hline & \multicolumn{2}{c}{ Swaziland } & & \multicolumn{2}{c}{ Mozambique } \\
\cline { 2 - 3 } \cline { 6 - 7 } & 2005 & 2025 & & 2005 & 2025 \\
\hline Irrigation & 229 & 292 & & 17 & 39 \\
Urban & 12 & 21 & & 75 & 182 \\
Other & 12 & 21 & & 5 & 32 \\
\hline Total & 253 & 334 & & 97 & 252 \\
\hline
\end{tabular}

diversion channels. Scattered water users have been aggregated according to their location. Return flows from irrigation areas have been included for the large-scale schemes.

\subsection{System analysis models}

Water allocation in a river basin is usually a two step process as given in Fig. 3. In the first step (A) hydrological modeling is applied to simulate the distributed rainfall and runoff processes in the catchment. This model is normally calibrated against observed flow sequences at selected stations along the basin. Given that, in most cases, observed runoff is already influenced by water uses the hydrological model is used to obtain naturalized or virgin flows of the catchment that represent the natural runoff conditions.

The naturalization of runoff is done by removing the known historic water uses from the model. For the Umbeluzi these values were obtained from the PITMAN rainfall-runoff model set up by SWECO and Associates (2005). The second level (B) of the system analysis concerns testing development scenarios of river basin development and water use. The model itself uses input of naturalized flow, river channels, dam characteristics, environmental flow requirements and scenarios of water use and afforestation. Different models approach water allocation differently but are all based on water balance in a network of nodes symbolizing the physical components of a river basin and links representing conduits of water between nodes (Wang and Hipel, 2003). Allocation principles and priorities for different uses are normally set in the models based on national and international policies and, in the transboundary case, on water sharing agreements if existing.

\subsubsection{Water Resources Yield Model (WRYM)}

WRYM was developed in South Africa by the BKS consulting firm based on the Canadian ACRES Reservoir Simulation Program (Mackenzie and van Rooyen, 2003). It relies on a solver that optimizes the water allocation in a river system based on a set of penalties for storage, channels and demands at various nodes and links. It minimizes a cost function based on storage and allocation deficit cost but also 


\section{UMBELUZI RIVER WATER RESOURCES SYSTEM}

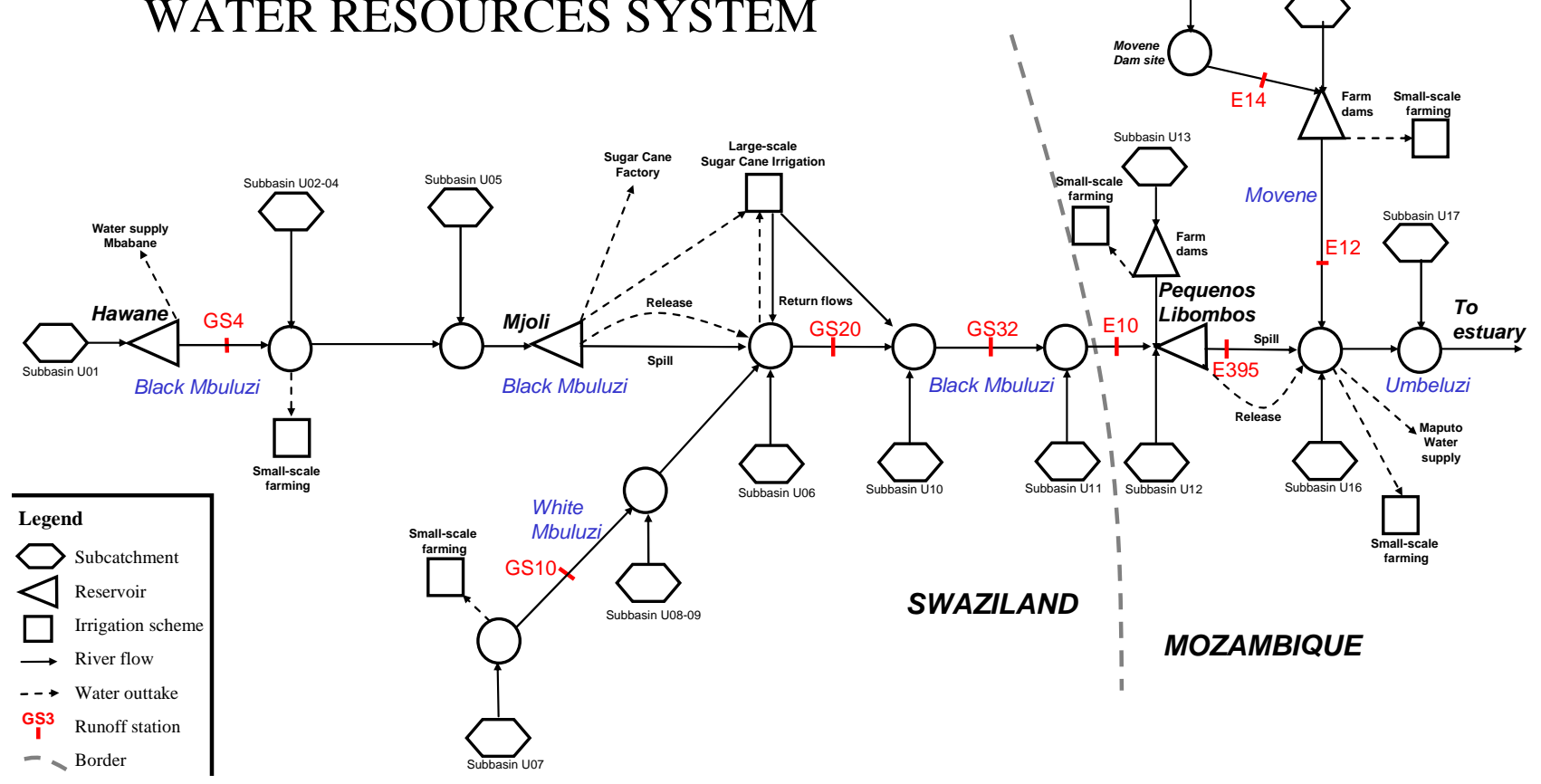

Fig. 2. Simplified Umbeluzi River basin system model schematic.

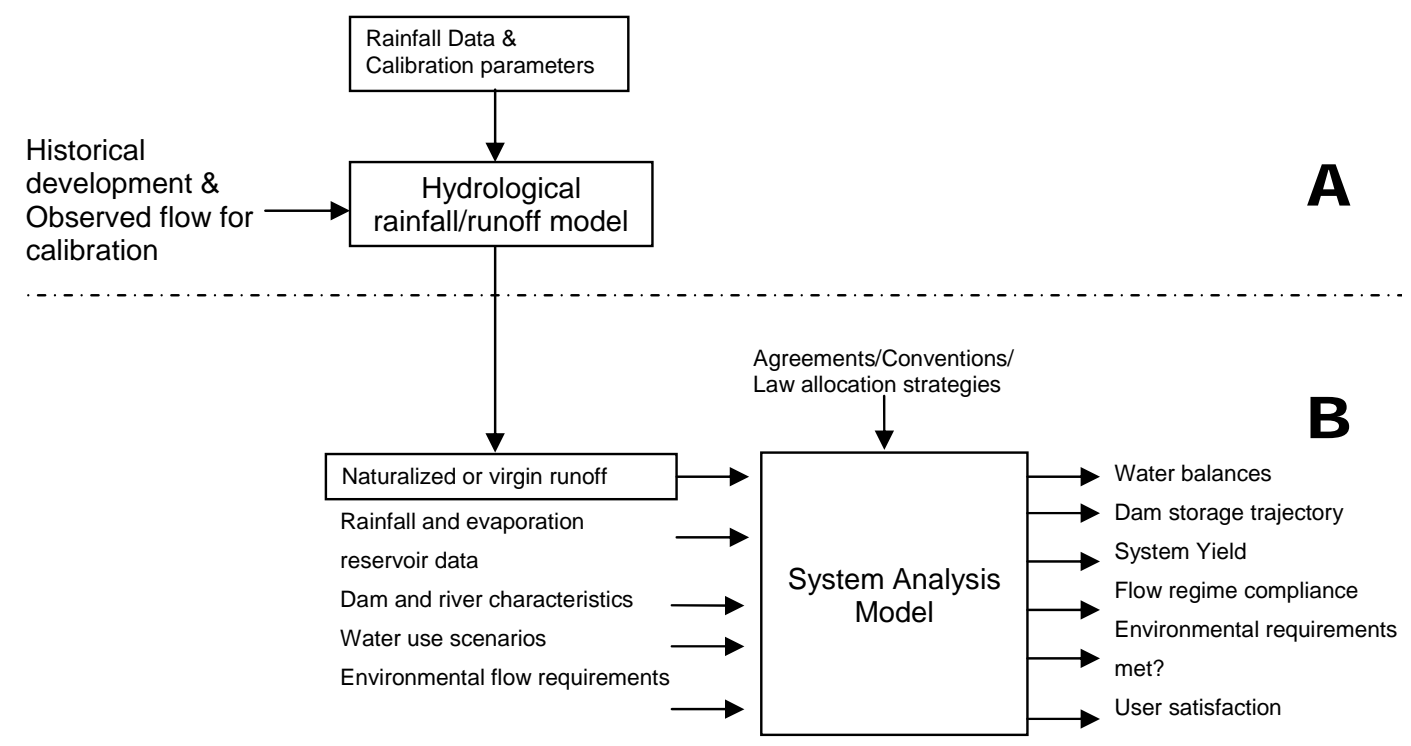

Fig. 3. Modeling for water resources allocation in international rivers. (A) and (B) denote the two steps normally used to obtain the information for water allocation.

between different forms of storage in a catchment (Mackenzie and van Rooyen, 1999). At the core of this model is a penalty structure used in the decision about storing or allocating water in the system. Penalties are assigned to links supplying water reservoirs and other sources to users and to distinguish between different forms of storage in reservoirs nodes and across the catchment. Grossmann et al. (1995) gives details of the use of network theory in linear programming to solve water allocation problems of water resources systems.

In the example shown in Table 2, the storage in the dam has been divided into four zones. The upper zone is above 
Table 2. Example of reservoir zones and penalty structure in the WRYM. Source: WRYM User Guide - 4.1.1.

\begin{tabular}{lrc}
\hline Storage & Penalty & Elevation \\
\hline $100 \%$ & 1000 & 1548.96 \\
$90 \%$ & 2 & 1547.99 \\
$0 \%$ & 20 & 1533.00 \\
$0 \%$ & 10000 & 1533.00 \\
Bottom & & 1521.95 \\
\hline
\end{tabular}

the full supply level (FSL) and has therefore a very high penalty. The second zone is between FSL and the $90 \%$ capacity. This zone has a penalty of 2 units. The third zone represents the water between the $90 \%$ level and the dead storage level (DSL). Water in this zone has a penalty of 20 units and represents the main working storage for the reservoir. The water between the DSL and the bottom of the dam has a relatively very high value of 10000 units. Thus the model will never draw water from this zone to meet the downstream demand. The four penalties used in the example have the effect of restricting the working storage of the dam to the second and third zones. In the model there are possibilities to have more zones than shown in the example.

Table 3 shows a typical penalty structure for a channel with a specified target draft (TD). Failing to meet the target draft results in a penalty of 250 units. If the target draft is supplied, there is a zero penalty and if it is exceeded, the excess flow results in a penalty of 20 units. For further explanation of the penalty structure of the WRYM model, see the User Guide 4.1.1 (Mackenzie and van Rooyen, 1999).

In WRYM the network is analyzed for each time period and solved with the selected penalty structures. The network solver will minimize the penalties for each time step by choosing the best allocation of water to the different users. It will also choose the most attractive route (i.e. minimum penalty) for transferring the water from the storage zones to the demand centers.

The WRYM is widely used in southern Africa and is the chosen tool by the South African Department of Water Affairs and Forestry for system analysis of all the river basins in South Africa (Carmo Vaz and van der Zaag, 2003).

\subsubsection{Water Allocation Flow model in Excel (WAFLEX)}

The WAFLEX model was first introduced by Savenije (1995) for water resources simulation. It is a simple water balance model that uses the basic spreadsheet capacity to simulate complex systems. It is easy to build and very transparent as everything takes place in EXCEL spreadsheets. Water allocation strategies of this model are based on a comparison of demand and availability. Reservoir operation is based on the division of the storage in different forms as given in Fig. 4.
Table 3. Example of link penalty in the WRYM. Source: WRYM User Guide - 4.1.1.

\begin{tabular}{lr}
\hline Range of flow & Penalty \\
\hline 0 to TD & 250 \\
TD & 0 \\
TD to infinity & 20 \\
\hline
\end{tabular}

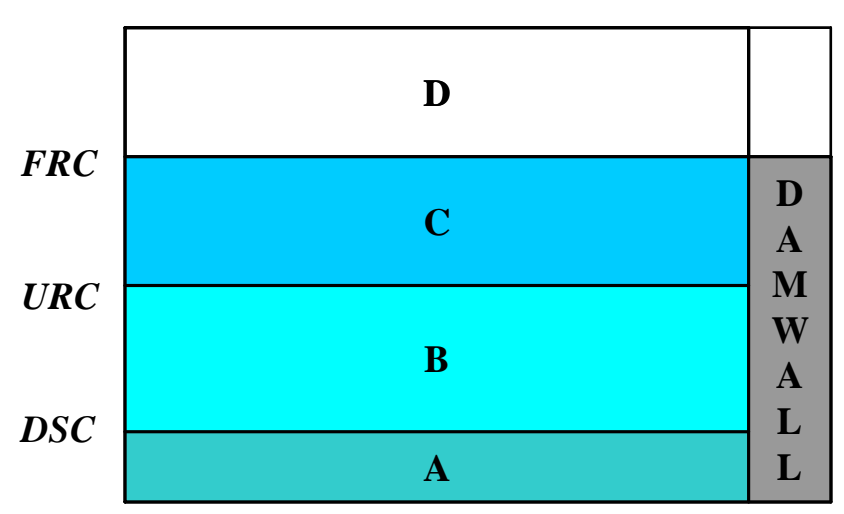

Fig. 4. Storage forms in WAFLEX.

The storage is divided in four zones. If the level of storage is under the Dead Storage Curve (DSC), no water will be released. If the level of storage is between the DSC and the Utility Rule Curve (URC) the release will be rationed as a factor of the demand. This is also known as hedging rules (Draper and Lund, 2004). The reduction factor which is set by the model developer is triggered at the URC threshold and is fixed throughout the deficit period. If the level of storage is between URC and Flood Rule Curve (FRC) the demands will be fully satisfied. At last, if the level of storage is above FRC the reservoir spills. In the WAFLEX, subsequent to reservoir release, the water is available to satisfy the demands in first come first serve order. It is, however, also possible to build more complex models by developing Macros that are routines designed to impose a designed sequence of allocating water to downstream users.

The network built up in the spreadsheet consists of a supply and a demand module. The demand module calculates in upstream direction to determine the demands for the reservoir release. The supply module calculates in downstream direction of the flow. Reservoir releases are calculated using macros in which the operation rule curves are used and the demands are determined by the demand module (Symphorian et al., 2003). This computation also includes reservoir losses through evaporation. 


\subsubsection{Water Evaluation and Planning system (WEAP21)}

WEAP21 was developed by Stockholm Environment Institute (SEI) and is widely used as a system analysis model (Sieber et al., 2002). WEAP21 operates on the basic principle of water balancing, accounting between supply and demand at various system nodes. WEAP2 1 also has a GIS function allowing the user to visualize the network on the screen and interactively modify or update the inputs of the model. In recent years this software has become popular in various research related to climate adaptation within UN organizations and others especially in research on effect of climate change on agriculture (Rosenzweig et al., 2004; Yates et al., 2005; Joyce et al., 2006).

The reservoir operation is similar to that of WAFLEX. During the rationing period only a fraction of the storage is available for release. However, an added complexity in this model is the possibility of using a priority rule to give preference for use of certain reservoirs for satisfying the demands. A reservoir with lower priority will empty faster than those with higher priorities. Furthermore, in the WEAP21 model there is a possibility of controlling the water that is supplied to different users once it is released from the reservoir. This is done through a priority rule that set preferences to higher valued uses such as urban water supply and environmental water requirements as compared to other water uses; the same range of priority values applies. In essence the mix of the set of supply and storage priority assigned to the network will drive the model and the water allocation.

\subsubsection{Comparison of the models}

All three models are explicit system analysis models and depend on input of distributed naturalized inflow calculated by other methods.

The main differences of the three models are how the decision to allocate water from storage is done. The WRYM is flexible in the way it approaches water allocation to different users in a catchment. The numerical optimization is essentially limited to the users downstream each reservoir. However, in case there are complex interconnections of reservoirs in the basin these can be incorporated in the model. The WEAP21 essentially follows a priority rule of allocation. The system water allocation is driven by water user priority versus reservoir priority allowing downstream users to benefit from any given upstream reservoir in the catchment. Also the allocation between users along the system will follow a priority rule given high preference to high value users. In WAFLEX water is allocated to downstream nodes connected to reservoirs. In order to enable an upstream reservoir to support a downstream it is necessary to build auxiliary functions that can only capture information from the time step before the one in computation. In other words it is more a compensation function than a direct support between the reservoirs.
In the case where reservoirs are located in tributaries feeding to a downstream canal leading to a user, the WRYM penalty structure allows for reservoirs to conjunctively operate to satisfy these demands in the catchment. The reservoirs with lowest penalties will be mobilized first to meet deficits of supply by another concurrent reservoir. WEAP 21 on the other hand is mostly based on comparative value of the reservoir and the user in question. Normally, users should have high priority value associated with their demands in order to profit from water in storage in a given reservoir. The order in which dams will be mobilized to meet the different deficits in downstream nodes is given by the priority in filling that is assigned to the reservoirs.

Table 4 gives a comparison of the main features and differences of the three system analysis models used in the Umbeluzi River basin.

\subsection{System configurations}

The schematic in Fig. 2 together with identified sites for new dams and expected future water outtakes was used as basis for all models. Naturalized monthly inflows from 1925 to 1999 for all the subbasins of the Umbeluzi River, produced by SWECO and Associates (2005), were used as input to all three models. As a basis for the water allocation, priorities were generally set according to the policies in southern Africa (SADC, 2000). All other inputs values such as reservoir net-evaporation, precipitation and demands for different scenarios are equally based on the study by SWECO and Associates (2005).

SWECO and Associates (2005) used a calibration methodology to set the penalty structure of the model. The basis for the calibration was the knowledge of present water management in the river basin and the observed runoff records. Realistic penalties could thus be found through an iterative process where simulated and observed river runoff was compared. In a similar manner the priorities for reservoirs and water uses were set in the WAFLEX and the WEAP21 (Table 5).

Table 5 shows that to enable a description of the historic and present water management in the Umbeluzi River basin the model parameters were set to values that partly contradict the international and national water policies. For instance, for failing to meet the demands of large-scale scale irrigation in Swaziland the WRYM penalties are set even higher than failing to meet urban water supply demands. On the other hand, the WRYM has included an equally high penalty for failing to meet the set minimum border flow determined by the 1976 bi-lateral agreement between the countries (Juizo et al., 2006) aiming at supporting the water supply of Maputo City.

In WAFLEX a central demand and supply module was introduced, which enabled to put the abstraction nodes downstream of the reservoirs in the order of preference. By using this module, irrigation was prioritized downstream of the 
Table 4. Summarized comparison of the three system analysis models used in the study. All models run on a monthly time step.

\begin{tabular}{|c|c|c|c|c|}
\hline Model & Allocation methodology & $\begin{array}{l}\text { Optimization } \\
\text { methodology }\end{array}$ & User friendliness & Transparency \\
\hline WRYM & $\begin{array}{l}\text { Minimizes system penalty based on } \\
\text { penalties per unit water set for releases } \\
\text { from reservoirs and for failing to meet } \\
\text { minimum flow requirements or } \\
\text { demands. } \\
\text { Higher penalties are given for failing } \\
\text { to meet prioritized water use. Different } \\
\text { penalties for same user type can be } \\
\text { given. }\end{array}$ & $\begin{array}{l}\text { A numerical } \\
\text { routine is run } \\
\text { optimization } \\
\text { for each time } \\
\text { step }\end{array}$ & $\begin{array}{l}\text { Software available at } \\
\text { DWAF, South } \\
\text { Africa. } \\
\text { Difficult to use } \\
\text { without thorough } \\
\text { training. }\end{array}$ & $\begin{array}{l}\text { Because of the complex } \\
\text { penalty structures and } \\
\text { system optimization } \\
\text { routine transparency is } \\
\text { limited. }\end{array}$ \\
\hline WAFLEX & $\begin{array}{l}\text { Releases from reservoirs are reduced } \\
\text { according to storage rates. } \\
\text { When released, as a base rule: first } \\
\text { comes, first served. However, } \\
\text { possibilities to include routines to } \\
\text { prioritize types of water uses. }\end{array}$ & $\begin{array}{l}\text { No } \\
\text { optimization }\end{array}$ & $\begin{array}{l}\text { Uses EXCEL } \\
\text { spreadsheets. } \\
\text { Lecture notes on the } \\
\text { development of the } \\
\text { models are available } \\
\text { from IHE-Delft. } \\
\text { Easy to use. }\end{array}$ & $\begin{array}{l}\text { For basic use the } \\
\text { spreadsheet } \\
\text { methodology makes it } \\
\text { transparent. However, } \\
\text { for non skilled users, if } \\
\text { special Macro functions } \\
\text { are applied it limits } \\
\text { transparency. }\end{array}$ \\
\hline WEAP21 & $\begin{array}{l}\text { Priorities are set for which reservoirs } \\
\text { to draw water from. Amount of water } \\
\text { for releases is reduced depending on } \\
\text { storage situation allowing for rationing } \\
\text { in times of deficit. } \\
\text { When released allocation downstream } \\
\text { is made according to given priorities } \\
\text { for each type of water use. } \\
\text { For equal priorities upstream users are } \\
\text { provided first. }\end{array}$ & $\begin{array}{l}\text { No } \\
\text { optimization }\end{array}$ & $\begin{array}{l}\text { GIS based interface } \\
\text { which gives good } \\
\text { overview of the river } \\
\text { system. } \\
\text { Software available } \\
\text { from SEI webpage. } \\
\text { Easy to use. }\end{array}$ & $\begin{array}{l}\text { Fairly transparent } \\
\text { through its GIS } \\
\text { interface and straight } \\
\text { forward priority system. }\end{array}$ \\
\hline
\end{tabular}

Table 5. Configuration used for the three system models applied for the Umbeluzi River basin. PQL=Pequenos Libombos, IFR $=$ Instream Flow Requirements, EFR = Estuarine Flow Requirements.

\begin{tabular}{|c|c|c|c|c|c|c|c|c|c|c|c|c|c|c|c|c|c|}
\hline \multicolumn{6}{|c|}{ WRYM } & \multicolumn{6}{|c|}{ WAFLEX } & \multicolumn{6}{|c|}{ WEAP2 1} \\
\hline \multicolumn{2}{|c|}{$\begin{array}{l}\text { Reservoir penalties for } \\
\text { working storage }\end{array}$} & \multicolumn{2}{|c|}{$\begin{array}{l}\text { Penalties for failing } \\
\text { to meet demand }\end{array}$} & \multicolumn{2}{|c|}{$\begin{array}{l}\text { Penalties for failing } \\
\text { to meet min channel } \\
\text { flows }\end{array}$} & \multicolumn{2}{|l|}{$\begin{array}{l}\text { Allocation } \\
\text { priorities } \\
\text { downstream } \\
\text { Hawane }\end{array}$} & \multicolumn{2}{|l|}{$\begin{array}{l}\text { Allocation } \\
\text { priorities } \\
\text { downstream } \\
\text { Mnjoli }\end{array}$} & \multicolumn{2}{|c|}{$\begin{array}{c}\text { Allocation } \\
\text { priorities } \\
\text { downstream PQL }\end{array}$} & \multicolumn{2}{|c|}{$\begin{array}{c}\text { Dam } \\
\text { priorities }\end{array}$} & \multicolumn{2}{|c|}{$\begin{array}{l}\text { User priorities in } \\
\text { Swaziland }\end{array}$} & \multicolumn{2}{|c|}{$\begin{array}{l}\text { User priorities in } \\
\text { Mozambique }\end{array}$} \\
\hline Hawane & 40 & Water supply & 350 & Border flow & 400 & IFR & 1 & IFR & 1 & IFR & 1 & Hawane & 2 & Water supply & 1 & Water supply & 5 \\
\hline Mnjoli & 10 & Industry & 340 & Releases from & & Water supply & 2 & Irrigation & 2 & Water supply & 2 & Mnjoli & 4 & IFR & 1 & IFR & 5 \\
\hline PQL & 30 & Livestock & 300 & Hawane & 250 & & & Water supply & 3 & Irrigation & 3 & PQL & 9 & Industry & 3 & Industry & 6 \\
\hline $\mathrm{MBF}$ & 30 & Large-scale & & Releases from & & & & Industry & 4 & Industry & 4 & $\mathrm{MBF}$ & 5 & Livestock & 3 & Livestock & 6 \\
\hline Isilele & 10 & Irrigation & 400 & Mnjoli & 250 & & & Livestock & 5 & & & Isilele & 5 & Irrigation & 4 & Irrigation & 7 \\
\hline Farm Dam & 10 & Small-scale & & Releases from & & & & & & & & Farm Dam & 5 & & & & \\
\hline \multirow[t]{3}{*}{ Movene } & 20 & Irrigation & 100 & PQL & 250 & & & & & & & Movene & 10 & & & & \\
\hline & & EFR & 250 & & & & & & & & & & & & & & \\
\hline & & Afforestation & 400 & & & & & & & & & & & & & & \\
\hline
\end{tabular}

Mnjoli Dam in favor for domestic water supply, while the opposite was done downstream of Pequenos Libombos (Table 5).

The WEAP21 parameters were also set according to the present praxis that the dams as first priority support the local users. The relatively lower priorities (higher penalty values) set for the Mozambique users and the Pequenos Libombos dam (Table 5) give the effect that no water from the Swaziland reservoirs is allocated to Mozambican users.

It should thus be noted that the internationally and nationally adopted policies for allocation (e.g. SADC 2000) are not strictly followed by the system analysis model, despite that 
Table 6. Scenario development for Umbeluzi River basin.

\begin{tabular}{lll}
\hline Scenario & Description & Comment \\
\hline 1 & -2005 for all users demands including environmental requirements; & Assessment of current situation. \\
& -2005 infrastructure (Dams at Hawane, Mnjoli and Pequenos Libombos). & \\
\hline 3 & -2025 demand for all users including environmental requirements; & $\begin{array}{l}\text { Impact of additional infrastructure in } \\
\text { meeting future demands. }\end{array}$ \\
& - Additional infrastructure, dams at Mbuluzi Falls, Isilele and Movene. & \\
\hline 4 & -2005 irrigation demand in both countries; & $\begin{array}{l}\text { The existing IncoMaputo Agreement } \\
\text { proposes that countries should reorient } \\
\text { there high demand uses to other system } \\
\text { with available water. In this scenario } \\
\text { system performance is tested for Movene. } \\
\text { increased demands except for } \\
\text { irrigation that is assumed to be } \\
\text { developed in the Maputo River basin. }\end{array}$ \\
& -2005 industrial demand Maputo & Environmental requirements; \\
& - Additional infrastructure, dams at Mbuluzi Falls, Isilele and &
\end{tabular}

they are stated as a basis for the modeling. The reason is that water resources have not, and are presently not, allocated according to these policies on the catchment scale in the Umbeluzi River. As a choice the model developer, in this case SWECO and Associates (2005) and the authors, thus chose to describe the river systems as it works today rather than how it would work if the SADC Protocol (SADC, 2000) was strictly followed.

The three models were developed to simulate three scenario developments in the basin (Table 6) targeting mainly three main demands in the system (i) urban water supply; (ii) irrigation development and (iii) environmental flow releases to the estuary for present (2005) and future conditions (2025). Scenario 1 uses the present infrastructure, while the other two scenarios include development of new dams. The specific demands for all present and future users were set equal in the three system analysis models.

\section{Results}

The results of the three models were compared in terms of level of satisfaction for different users and the dam behavior. The level of satisfaction is the ratio between supplied water and demand for the whole period of modeling.

The models' natural runoff input covered a period of 75 years (1925-1999). Through the long series, the models can thus provide estimates of the available water resources for different demand and infrastructure scenarios taking into account the climatic variability of southern Africa.

Despite differences in the level of satisfaction that can be seen for specific demands and scenarios, all models perform similarly (Table 7). As expected when comparing 2005 and 2025 (Scenarios 1 and 3) the level of satisfaction decreases for the large users (e.g. large-scale irrigation and
Table 7. Level of satisfaction for the main users.

\begin{tabular}{|c|c|c|c|}
\hline & WRYM & WAFLEX & WEAP21 \\
\hline \multicolumn{4}{|c|}{ Scenario 1 (2005 demand level) } \\
\hline Mbabane water supply & $100 \%$ & $99 \%$ & $98 \%$ \\
\hline $\begin{array}{l}\text { Large-scale irrigation } \\
\text { Swaziland }\end{array}$ & $100 \%$ & $95 \%$ & $99 \%$ \\
\hline $\begin{array}{l}\text { Small-scale irrigation } \\
\text { Mozambique }\end{array}$ & $97 \%$ & $94 \%$ & $97 \%$ \\
\hline Maputo Water supply & $99 \%$ & $97 \%$ & $98 \%$ \\
\hline \multicolumn{4}{|c|}{ Scenario 3 (2025 demand level, new infrastructure) } \\
\hline Mbabane water supply & $98 \%$ & $100 \%$ & $100 \%$ \\
\hline $\begin{array}{l}\text { Large-scale irrigation } \\
\text { Swaziland }\end{array}$ & $88 \%$ & $86 \%$ & $88 \%$ \\
\hline $\begin{array}{l}\text { Small-scale irrigation } \\
\text { Mozambique }\end{array}$ & $48 \%$ & $41 \%$ & $47 \%$ \\
\hline Maputo Water supply & $69 \%$ & $69 \%$ & $68 \%$ \\
\hline \multicolumn{4}{|c|}{$\begin{array}{c}\text { Scenario } 4 \text { (2005 demand for irrigation, } 2025 \\
\text { demand for water supply,) }\end{array}$} \\
\hline Mbabane water supply & $100 \%$ & $100 \%$ & $98 \%$ \\
\hline $\begin{array}{l}\text { Large-scale irrigation } \\
\text { Swaziland }\end{array}$ & $88 \%$ & $89 \%$ & $88 \%$ \\
\hline $\begin{array}{l}\text { Small-scale irrigation } \\
\text { Mozambique }\end{array}$ & $70 \%$ & $57 \%$ & $62 \%$ \\
\hline Maputo Water supply & $84 \%$ & $76 \%$ & $77 \%$ \\
\hline
\end{tabular}

Maputo City). It shows that the additional storage capacities introduced are not sufficient to balance the increased water demand (Table 1) on the catchment scale. Only for small users in the upper Umbeluzi and in the tributaries, the additional reservoir storages compensate for the increased 
demand (e.g. for Mbabane water supply). Even when irrigation development is restricted and new infrastructure is put in place (Scenario 4), the level of satisfaction for urban water supply to Maputo does not reach acceptable levels.

A comparison of the dynamics of the main reservoirs (exemplified for Mnjoli Dam in Fig. 5) confirms that the three models perform similarly.

A more detailed examination of the results of the three models shows that the WRYM model has a totally larger level of satisfaction for all users, although the difference is not large (Table 8). For specific users the models may also give different results. An example is the small-scale irrigation that shows significant differences in satisfaction levels for the three models (Table 7). Since satisfaction levels are closely linked to the production yield the different model results may therefore affect the judged feasibility of these irrigation schemes. Also the satisfaction levels for Maputo City show varying levels, although all three models predict levels far below what is acceptable for urban supply for both Scenarios 3 and 4.

Another way of expressing how the models performed in meeting demands is to calculate the assurance of supply (Wurb, 2005), i.e. for how many months of the total period the demand was fully supplied. All three model results for assurance of supply were similar to those for satisfaction levels. A trend was, however, that assurance of supply is generally lower than satisfaction level for the users located in small tributaries with limited upstream storages.

\section{Discussion}

The results of the three system analysis models applied for the Umbeluzi River basin in this study revealed two general and essential findings:

1. Different system analysis models may give differences in satisfaction levels for specific water users although the same governing input variables are used.

2. The degrees of freedom in all three system analysis models are very large and thus the model developper has huge power to allocate water although the models are generally described to follow the internationally accepted allocation principles.

The differences in satisfaction levels for specific water users found in this study most probably depend on the different ways water allocation and prioritization are structurally handled in the three models. In general terms the prioritization between different users were described similarly in all models but the exact levels of satisfaction still differed. In the water scarce situation, as described by Scenario 3 where total demand is higher than the available water resources, all three models gave higher level of satisfaction to the large-scale irrigation in Swaziland compared to all the downstream users
Table 8. Total level of satisfaction for all users in the Umbeluzi River.

\begin{tabular}{lccc}
\hline & WRYM & WAFLEX & WEAP21 \\
\hline Scenario 1 & $99 \%$ & $97 \%$ & $99 \%$ \\
Scenario 3 & $84 \%$ & $79 \%$ & $79 \%$ \\
Scenario 4 & $88 \%$ & $85 \%$ & $85 \%$ \\
\hline
\end{tabular}

in Mozambique. So in general terms all models allocated water as intended. But the level of satisfaction calculated with the three models for specific users could vary with up to 10-20\% units, especially for smaller users. Such differences may give a significant difference in the long-term feasibility of the applied agriculture. On the other hand, the application of the three models showed that for large-scale users all three models gave similar satisfaction levels as seen by Table 7 .

The differences in satisfaction levels due to the different structure of the models are, however, completely overridden by the different results that can be obtained through changing the allocation priorities in the models. The set up of the three system analysis models for Umbeluzi River illustrated that the allocation principles stated by the international and national policies are difficult to apply. In the Umbeluzi case the model developers set up the prioritization according to how the water has been allocated historically. The reason was that the model developers judged this as the most probable scenario in the future. The Mnjoli Dam was constructed by, and for, the sugar cane estates in Swaziland and the Pequenos Libombos dam was constructed by the Government of Mozambique for water supply to Maputo City. History shows that it is very difficult to change allocation patterns and, faced with the task to predict future water resources management, the model developer chose the most likely allocation forecast, which is that things will be as they always have been. SWECO and Associates (2005) made a sensitivity analysis for the Umbeluzi River basin and found that by changing the penalties in the WRYM model to favor the downstream Maputo water supply the assurance of supply could be increased with $30 \%$ for the City and that overall satisfaction levels could be slightly increased for the whole catchment. This of course led to decreased assurances of supply for the upstream irrigation schemes. If the prioritizations for water user types in Swaziland and Mozambique in the WEAP21 (Table 6) were set equal, the results would have been similar. Then water would have been drawn from the Mnjoli to support Maputo City before allocating water to the irrigation schemes.

What is essential is whether the stakeholders realize that these choices have been made by the model developer. The system analysis models are generally described to follow the international praxis of water allocation, and even if the input data and parameters are reported in detail the stakeholders 


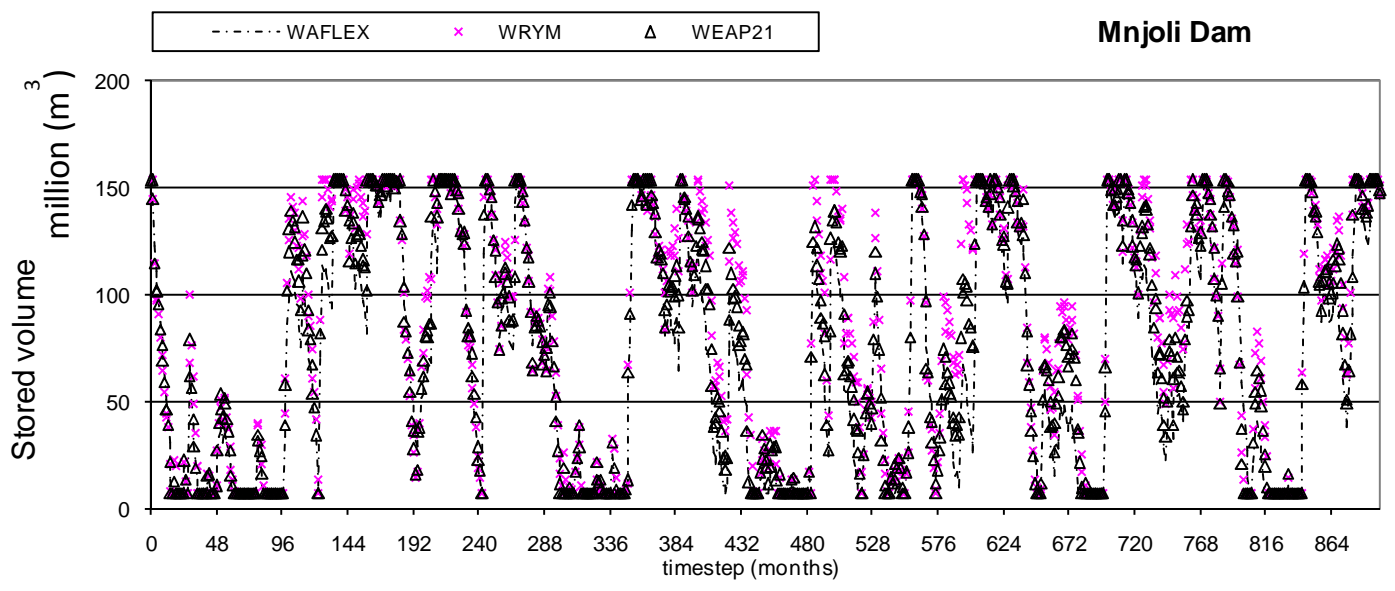

Fig. 5. Model performance for Mnjoli dam operation for Scenario 3. Reservoir trajectory during 75 years of simulation.

normally lack the knowledge to comprehend them. This is why the transparency and user friendliness of the models are important factors in the system analysis. If there is no understanding or transparency of the system analysis modeling, considerable trust must exist between the stakeholders and the model developer (Chapman et al., 1995). Such trust has been developed between the Department of Water Affairs and Forestry and the consultants running the WRYM in South Africa. Despite that the WRYM model is complicated to use and has limited transparency it is therefore chosen as the preferred tool in South Africa for water resources allocation. In transboundary rivers in southern Africa the same trust does not exist between the model developers, which are often South African, and the other governments acting as stakeholders.

It may therefore be necessary to review the process of water resources planning and allocation in transboundary rivers in southern Africa. An important step is to agree on the allocation principles and the modeling procedure before the models are applied. This goes beyond the general principles already agreed in the SADC Protocol. The principles and procedures may be different depending on the local or regional situation for the different rivers. This step also includes the choice of model tool, model developer and a procedure on how to make the modeling transparent to as many stakeholders as possible. Capacity building of the stakeholders is obviously a key factor in this process.

This study may give advice on the choice of system analysis tool. All three models applied to the Umbeluzi Rivers have the functions necessary to make a system analysis of water resources in a river basin in southern Africa. The WEAP model, by its priority rule based allocation, seems to give the best possibility to maximize water use in a whole river basin by allowing reservoirs to support each other in times of scarcity. For river basin systems that are even more complicated and where water has a high price, e.g. systems including large hydropower schemes or large interbasin transfers for thermo power cooling that require high reliability of supply, the WRYM models may be advantageous to the WAFLEX and WEAP21.

The numerical optimization to find the least penalty for each time step may be the reason why the WRYM gives totally slightly higher satisfaction levels than the two other models, as seen by Table 8 . On the other hand, the simpler allocation algorithm used in the WAFLEX model, basically upstream to downstream for each water use type, may be more close to how water is actually allocated in reality in the river basins. It may therefore be more close to the actual future satisfaction levels taking into account human's inability to operate a whole river system optimally. The WAFLEX and the WEAP21 also have an advantage in being more transparent and user friendly compared to the WRYM.

The use of all three models, however, demands thorough understanding of system analysis. The experience of applying the three models to the Umbeluzi River is that mistakes are easily made when the individual penalties and priorities are set. Neither of the models have any quality assurance module, which means that it is up to the model developer's experience and knowledge to identify errors and judge the reasonability of the model results. The application of the three system analysis models to the Umbeluzi River basin further showed that there is not one single solution for the water allocation. Depending on the parameters set or the model used, different results can be obtained as seen in Table 7. None of these results can be said to be more correct than the other. 


\section{Conclusions}

In this study we have investigated the implications of applying three different system analysis models for water allocation in an international river basin. The results show that the three models, WRYM, WAFLEX and WEAP21, all are adequate tools for system analysis of river basins in southern Africa, although the structure and complexity of the models are different. The obtained level of satisfaction for specific water users could, however, vary depending on which model was used, which causes uncertainties if an individual model is applied directly for studying the feasibility of water demanding development. The reason for the diverse results is the structurally different ways of describing allocation and prioritization of water in the three models. However, the large degrees of freedom in all system models cause even larger uncertainty in the results since the model developer can, intentionally or unintentionally, direct the results to favor certain water users. These uncertainties are often unknown for the stakeholders and policy makers, who use the results of the system analysis models to plan future water allocation.

The water allocation in Umbeluzi River for future development scenarios is faced with considerable difficulties as the future demands can not be fully met even with an increase in reservoir storages. This study shows that planning of future water allocation in this transboundary river is difficult through straightforward application of system analysis models. Prior to modeling, the main stakeholders have to agree on the specific allocation principles and the modeling procedure to apply for the specific river basin in question. General principles such as the SADC Protocol are not sufficient basis for the system analysis. To enable joint agreement on the principles to apply and to quality assure the results, significant capacity of system analysis must exist among the main stakeholders. Furthermore, transparency of the system analysis modeling is a key for the joint acceptance of the results. Alternatively, trust must be built between the stakeholders and the system analysis model developers, something that is difficult in transboundary river basins.

This study illustrates the possibility for the introduction of other modeling packages for water resources allocation in transboundary rivers in southern Africa beyond the WRYM, which has been adopted as the preferred tool but has been questioned because of its complexity and limited transparency. For complex river basin systems the WRYM model most probably is the best tool but in many cases the WAFLEX and WEAP21 may be good alternatives. The advantage of these models compared to the WRYM is that they are relatively user friendly and transparent.

The conclusion of this study is that the choice of model does not per se affect the decision of best water allocation and infrastructure layout of a shared river basin. The chosen allocation and prioritization principles for the specific river basin and the model developer's experience and integrity are more important factors to find the optimal and equitable allocation. This has to be realized by stakeholders and policy makers in order to improve the water resources planning and allocation in transboundary rivers in southern Africa. This study also shows the importance of river basin conceptualization as a key element in preparation for allocation.

Acknowledgements. This work received financial support from SIDA-SAREC. The authors are thankful to all those who provided data for this research. We also wish to thank Stockholm Environmental Institute (SEI) for providing a free WEAP21 licence to UEM and DWAF for providing the WRYM software.

Edited by: P. van der Zaag

\section{References}

Carmo Vaz, A. and van der Zaag, P.: Sharing the Incomati waters: co-operation and competition in the balance: From potential conflict to co-operation potential, UNESCO/IHP/WWAP/IHPVI/Technical Documents in Hydrology/PC-CP Series/n. 14, 2003.

Chapman, R. A., Manders, P. T., Scholes, R. J., and Bosch, J. M.: Who should get the water? Decision support for water resource management, Water Sci. Technol., 32(5-6), 37-43, 1995.

Consultec and BKS Acres: Joint Inkomati Basin Study: Phase 2, Tripartite Permanent Technical Committee, Kingdom of Swaziland - Republic of Mozambique - Republic of South Africa, 2000.

de Groot, R. and Oosterwijk, W.: Water Resources Study of the Maputo River Basin: Creating a water resources yield model for the Maputo river basin, M.Sc. report, Delft University of Technology (TU-Delft), Delft, The Netherlands, 2006.

Dent, M.: Installed water resource modelling systems for catchment management agencies, Water SA, 27(3), 333-340, 2001.

Draper, A.J, Lund, J.R.: Optimal Hedging and Carryover Storage Value, Journal of Water Resources Panning and Management, ASCE, January/February, Vol. 130, no 1,pp 83-87, 2004.

Grossmann, W., Guariso, G., Hitz, M., and Wethner, H.: A Min Cost Solution for Dynamic Assignment Problems in Networks with Storage Devices, Manage. Sci., 41(1), 83-93, 1995.

Joyce, B., Vacuña, S., Dale, L., Hanemann, M., Purkey, D., and Yates, D.: Climate change impacts on water for agriculture in California: A case study in the Sacramento Valley, California Climate Change Center, White Paper, CEC-500-2005-194-SF, California, USA, 2006.

Juizo, D., Lidén, R., and Carmo Vaz, A.: Remaining Challenges for bi-national agreements on shared water: The Umbeluzi case, Water Policy, 8, 231-253, 2006.

Le Roy, E.: A study of the development of water resources in the Olifants catchment, South Africa: Application of the WEAP model, M.Sc. report, Imperial College, London, 2005.

Lévite, H. and Sally, H: Linkages between Productivity and equitable allocation of water, Phys. Chem. Earth, 27, 825-830, 2002.

Mackenzie, R. S. and van Rooyen, P. G.: Water Resources Yield Model: User Guide - Release 4.1.1, Department of Water Affairs (DWAF), South Africa, 1999.

Mackenzie, R. S. and van Rooyen, P. G.: Management large water resources systems, Water Supp., 3(3), 297-304, 2003. 
Nkomo, S. and van der Zaag, P.: Equitable water allocation in a heavily committed international catchment area: the case of the Komati Catchment, Phys. Chem. Earth, 29, 1309-1317, 2004.

Raju, K. S. and Pillai, C. R. S.: Multicriterion decision making in river basin planning and development, Eur. J. Oper. Res., 112, 249-257, 1999.

Rosenzweig, C., Strzepek, K. M., Major, D. C., Iglesias, A., Yates, D. N., McCluskey, A., and Hillel, A.: Water resources for agriculture in a changing climate: international case studies, Global Environ. Change, 14, 345-360, 2004.

SADC: Revised Protocol on Shared Watercourses in the Southern African Development Community (SADC), 2000.

Savenije, H. H. G.: Spreadsheets: Flexible tools for integrated management of water resources in river basins, IAHS Publications, 231, 741-744, 1995.

Sengo, D.J., Kachapila, A., van der Zaag, P., Mul, M., and Nkomo, S.: Valuing the environmental water pulses into the Incomati estuary: Key to achieving equitable and sustainable utilisation of transboundary waters, Phys. Chem. Earth, 30, 648-657, 2005.

Sieber, J., Huber-Lee, A., and Raskin, P.: WEAP: Water Evaluation And Planning System User Guide (for WEAP21), Stockholm Environmental Institute - Boston, and Tellus Institute, User Guide for WEAP21, Boston, MA, 2002.
Sweco in association with Consultec Lda, Impacto Lda, BKS, Knight Piésold: Joint Umbeluzi River Basin Study: Final Report, Report prepared for the Government of the Republic of Mozambique and the Government of the Kingdom of Swaziland, 2005.

Symphorian, G. R., Madamombe, E., and van der Zaag, P.: Dam operation for environmental water releases; the case of Osborn Dam, Save Catchment, Zimbabwe, Phys. Chem. Earth, 28, 985993, 2003.

Van der Zaag, P., and Bolding, A.: Water governance in the Pungwe river basin: institutional limits to the upscaling of hydraulic infrastructure, in: Transboundary water governance in Southern Africa; examining underexplored dimensions, edited by: Swatuk, L. A. and Wirkus, L., Nomos, Bonn, 163-177, 2009.

Van der Zaag, P. and Carmo Vaz, Á : Sharing the Incomati waters: cooperation and competition in the balance, Water Policy, 5, 349-368, 2003.

Wang, L. F. and Hipel, W. K.: Cooperative water resources allocation based on equitable rights, Proceedings of the 2003 IEEE International Conference on Systems, Man and Cybernetics, Washington, USA, 5-8 October, 2003.

Wurb, R. A.: Modeling river/reservoir system management, water allocation, and supply reliability, J. Hydrol., 300, 100-113, 2005.

Yates, D., Siber, J., Purkey, D., and Huber-Lee, A.: WEAP21A Demand-, Priority-, and Preference-Driven Water Planning Model Part 1: model characteristics, Water Int., 30(4), 487-500, 2005. 